\title{
Increasing Carbon-to-Phosphorus Ratio (C:P) from Seston as a Prime Indicator for the Initiation of Lake Reoligotrophication
}

\author{
Beat Müller,* Thomas Steinsberger, Arno Stöckli, and Alfred Wüest \\ Cite This: Environ. Sci. Technol. 2021, 55, 6459-6466 \\ Read Online
}

ABSTRACT: Decline in total phosphorus (TP) during lake reoligotrophication does not apparently immediately influence carbon assimilation or deep-water oxygen levels. Traditional monitoring and interpretation do not typically consider the amount of organic carbon exported from the productive zone into the hypolimnion as a measure of net ecosystem production. This research investigated the carbon-to-phosphorus ratios of suspended particles in the epilimnion, $(\mathrm{C}: \mathrm{P})_{\mathrm{epi}}$, as indicators of changing productivity. We report sestonic C:P ratios, phytoplankton biomass, and hypolimnetic oxygen depletion rates in Lake Hallwil, a lake whose recovery from eutrophic conditions has been documented in 35 years of historic water-monitoring data. This study also interpreted long-term $(\mathrm{C}: \mathrm{P})_{\mathrm{epi}}$ ratios

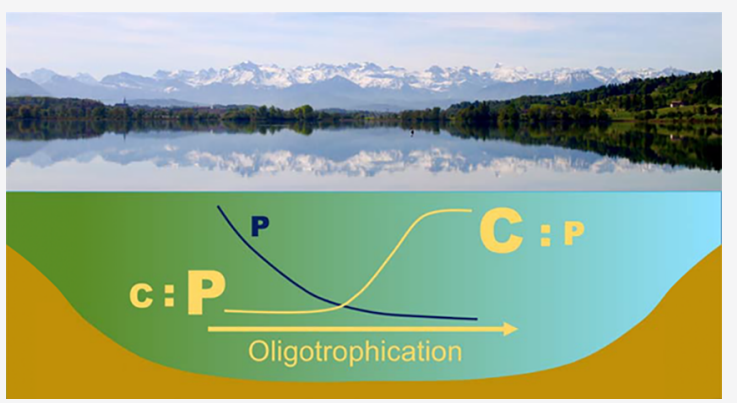
from reoligotrophication occurring in four other lakes. Lake Hallwil exhibited three distinct phases. (i) The (C:P) epi ratio remained low when TP concentrations did not limit production. (ii) (C:P) $)_{\mathrm{epi}}$ increased steadily when phytoplankton began optimizing the declining $\mathrm{P}$ and biomass remained stable. (iii) Below a critical TP threshold of $\sim 15$ to $\sim 20 \mathrm{mg} \mathrm{P} \mathrm{m}^{-3}$, (C:P) $)_{\text {epi }}$ remained high and the biomass eventually declined. This analysis showed that the $(\mathrm{C}: \mathrm{P})_{\mathrm{epi}}$ ratio indicates the reduction of productivity prior to classic indicators such as deep-water oxygen depletion.

\section{INTRODUCTION}

Limiting phosphorus $(\mathrm{P})$ loads in lakes can diminish primary production and thereby reduce hypolimnetic oxygen $\left(\mathrm{O}_{2}\right)$ depletion. Phosphorus reduction can also reduce the frequency and severity of harmful algal blooms and sustain the habitat for fish and other species that are sensitive to hypoxia. Various mitigation measures have successfully reduced $\mathrm{P}$ loads, ${ }^{1,2}$ but the effects of $\mathrm{P}$ reduction on primary production tend to show little change in deep-water $\mathrm{O}_{2}$ consumption during the early phases of recovery from eutrophication. ${ }^{3-5}$ Changes in primary production and subsequent hypolimnetic $\mathrm{O}_{2}$ consumption may become evident only at TP concentrations significantly lower than those previously expected. ${ }^{4}$ Oxidation of sediment layers and their reduced substances may limit improvements in hypolimnetic $\mathrm{O}_{2}$ concentrations. ${ }^{6,7}$ Furthermore, primary production in lakes varies seasonally and interannually, and the detection of trends in the rates of production typically depends on the long-term monitoring data. However, the decline of $\mathrm{P}$ availability below a critical threshold restrains cellular growth ${ }^{7}$ and phytoplankton biomass. This would appear as lower concentrations of $\mathrm{P}$ fractions relative to assimilated carbon. ${ }^{8,9}$ At the initial decrease of the P supply, the $\mathrm{C}: \mathrm{P}$ ratio may not correspond well with changes in the growth rate because of the luxury consumption of $\mathrm{P}$. At a subsequent stage, an increase in the C:P ratio of the phytoplankton community can indicate physiological adaptation and compensation in response to reduced $\mathrm{P}$ availability, while growth rates are still unaffected. A change in the C:P ratio of the suspended organic particles in the productive zone of a lake (represented as $(\mathrm{C}: \mathrm{P})_{\mathrm{epi}}$ ) could therefore serve as a more immediate indicator of phytoplankton response to the decline of bioavailable $\mathrm{P}$, even though some aspects of water quality have not fully recovered. A complementary analysis of the $\mathrm{C}: \mathrm{P}$ ratio could test the hypothesis that this transition occurs earlier than the time frame traditionally interpreted from long-term lake-monitoring data.

Phytoplankton communities in oceans ${ }^{10}$ and freshwater lakes ${ }^{11-13}$ show the ability to adjust and optimize their biomass production in response to changing nutrient supplies. Phosphorus is essential for the formation of nucleic acids, membrane lipids, and polyphosphates in all organisms. ${ }^{14}$ Phytoplankton has a wider dynamic range than zooplanktons or bacteria. ${ }^{15}$ At an excessive $\mathrm{P}$ supply, it can take up and store $\mathrm{P}$ in excess of its requirements, which is known as luxury uptake. $^{16,17}$ When primary production is limited by the availability of $\mathrm{P}$, the pathways for a more efficient $\mathrm{P}$ use facilitate continued carbon assimilation and biomass production. High elemental C:P ratios of seston, provided that seston

Received: December 17, 2020

Revised: March 19, 2021

Accepted: March 19, 2021

Published: April 2, 2021 
consists mainly of autochthonous particles, have been observed in oligotrophic lakes ${ }^{18,19}$ but not in eutrophic lakes. ${ }^{20,21}$ The $\mathrm{C}: \mathrm{P}$ ratios vary strongly over the season because of the varying $\mathrm{P}$ availability in the photic zone. The ratio is usually low at the beginning of the productive season in spring and then increases as bioavailable $\mathrm{P}$ becomes scarce. ${ }^{22}$ Hence, the C:P ratio of seston changes rapidly and with apparent precision in response to the changing nutrient availability. This could explain why dynamic changes in biomass show some degree of independence relative to available $\mathrm{P}$. Based on laboratory experiments, Healey and Hendzel ${ }^{23}$ interpreted the planktonic C:P ratios $<129$ as not imposing $\mathrm{P}$ limitation on growth, whereas the C:P ratio ranging from 129 to 258 represented moderate $\mathrm{P}$ deficiencies, and higher $\mathrm{C}: \mathrm{P}$ values were categorized as extremely P-deficient. Their study further suggested that C:P ratios may serve as sensitive indicators of lake phytoplankton community response to $\mathrm{P}$ mitigation efforts. The ability of phytoplankton communities to adapt to decreasing $\mathrm{P}$ supply through more efficient $\mathrm{P}$ use could hinder reoligotrophication processes, such as epilimnetic carbon export, and could delay the expected increases in hypolimnetic $\mathrm{O}_{2}$ concentrations.

In this study, we have analyzed a 35-year record of phytoplankton $\mathrm{C}: \mathrm{P}$ ratios and hypolimnetic $\mathrm{O}_{2}$ depletion in Lake Hallwil. Lake TP concentrations have decreased from a maximum value of $\sim 240 \mathrm{mg} \mathrm{P} \mathrm{m}^{-3}$ from the mid-1970s to $\sim 13$ $\mathrm{mg} \mathrm{P} \mathrm{m}{ }^{-3}$ in recent years. Correspondingly, the data set covers the transition from a eutrophic to an oligotrophic status and allows for a detailed interpretation. The findings are compared with historic data sets from four other lakes with similar trophic conditions. Observations confirm that the $\mathrm{C}: \mathrm{P}$ ratio detects the onset of $\mathrm{P}$ limitation in the course of lake reoligotrophication.

\section{MATERIALS AND METHODS}

2.1. Study Site. Located on the Swiss Plateau, Lake Hallwil is a $9.95 \mathrm{~km}^{2}$ large lake with a maximum depth of $46.5 \mathrm{~m}$, a mean depth of $28.6 \mathrm{~m}$, a volume of $0.29 \mathrm{~km}^{3}$, and a water residence time of 4.0 years (Table S2). The lake is currently recovering from eutrophic conditions that peaked in the 1970 s when total phosphorus concentrations after winter turnover $\left(\mathrm{TP}_{\text {mix }}\right)$ reached values of $\sim 240 \mathrm{mg} \mathrm{P} \mathrm{m}^{-3}$. Excessive algal growth, fish kills, and anoxic conditions in the hypolimnetic waters during the stratified summer season led to the installation of an aeration system similar to that installed a few years earlier in Lakes Baldegg and Sempach. ${ }^{24-26}$ Artificial aeration since 1986 supplies up to $700 \mathrm{t}$ of molecular $\mathrm{O}_{2}$ during each productive season but does not impact natural stratification. During winter, compressed air transmitted through the water column supports natural convective mixing (no ice cover, complete mixing in winter) and thereby enhances $\mathrm{O}_{2}$ uptake from the atmosphere. In spite of these efforts, the volume-averaged mean $\mathrm{O}_{2}$ concentration in the hypolimnion (below $15 \mathrm{~m}$ water depth) falls below $2 \mathrm{~g} \mathrm{O}_{2} \mathrm{~m}^{-3}$ toward the end of the stratified season for $70 \%$ of all summer seasons, as documented by the monitoring data (Figure S1).

Combined efforts of industry and agriculture have led to a decline in TP concentrations since 1980 to the current levels of $\sim 13 \mathrm{mg} \mathrm{P} \mathrm{m}{ }^{-3}$ (average from 2016-2020). Chapter S1 describes the development of the bioavailable P loads in Lake Hallwil since the mid-1980s (Figure S2). Since 2000, the planktonic community is dominated by $P$. rubescens, a non- $\mathrm{N}_{2}$ fixing cyanobacterium. ${ }^{27}$
2.2. Sampling and Chemical Analyses. Researchers have reported sporadic chemical analyses from Lake Hallwil since the 1960s, but regular, extensive monitoring began in 1985 , one year prior to the initiation of artificial aeration. Monitoring includes monthly vertical profiling of the water column using multiparameter probes that measure temperature, conductivity, $\mathrm{O}_{2}$, and $\mathrm{pH}$ (Hydropolytester, Züllig, Rheineck, Switzerland, until 1999, then a YSI multiparameter probe including fluorometry for chlorophyll-a until 2015, then a YSI EXO2 with a combined sensor for chlorophyll/ cyanobacterial pigments, Yellow Springs, USA, used until present). Water samples were collected at 15 different depth levels first monthly until 1997 and then five times per year thereafter (March, May, August, October, and December). The samples integrating the water column between 0-13 and 13-45 m depths were collected monthly with a specially constructed tubing system further described in chapter S2. Particulate organic carbon (POC) and particulate phosphorus (PP) from all water samples were analyzed directly from filters (glass fiber filters for POC and cellulose acetate filters for PP). Chapter S2 describes the analysis. As the metalimnetic temperature gradient extends from 10-15 m depth between May and mid-November, a sampling depth of $13 \mathrm{~m}$ is interpreted as spanning the epilimnion.

A sediment trap was installed at $30 \mathrm{~m}$ depth in Lake Hallwil over a 3 year period (2014-2016). The trap consisted of a pair of $70 \mathrm{~cm}$ long and $7 \mathrm{~cm}$ wide (inner diameter) plexiglass tubes. The material was collected monthly, freeze-dried, and then weighed. The dried material was ground in an agate mortar and analyzed for total organic carbon (TOC), total carbon (TC), total inorganic carbon (TIC), and TP according to the protocols described in chapter S2.

Long-term data from a Swiss lake-monitoring program allowed the estimation of C:P ratios of suspended particulate matter in the epilimnion (C:P) $)_{\text {epi }}$ for Lakes Geneva (19862019), Lucerne (1982-2020), Pfäffikon (1985-2008), and Türlersee (1987-2008). This study reports C:P as the molar ratios calculated using the mean epilimnion concentrations (15 $\mathrm{m}$ depth) from April to October. PP and POC were analyzed for all lakes (Lucerne only from 1982-2012) using membrane and glass fiber filters, respectively. Concentrations of PP and POC from Lake Lucerne (from 2013-2020) were calculated as the respective differences in TP and total dissolved P (TDP) and in TOC and dissolved organic C (DOC). The use of the types of filters differing in pore size may introduce bias in the estimated C:P ratios, which could not be further characterized, however.

2.3. Estimation of Areal Hypolimnetic Mineralization Rates. The areal hypolimnetic mineralization rate (AHM) expresses average per day $\mathrm{O}_{2}$ consumption in the stratified hypolimnion during the productive summer season plus $\mathrm{O}_{2}$ consuming equivalents of the reduced compounds present in the water column such as methane and ammonium. ${ }^{6}$ In practice, the estimates of $\mathrm{O}_{2}$ content in the hypolimnion (below $15 \mathrm{~m}$ depth) integrate the discrete $\mathrm{O}_{2}$ concentrations of the vertical profiles multiplied by the associated water layer volumes. The concentrations of $\mathrm{NH}_{4}^{+}, \mathrm{NO}_{2}^{-}, \mathrm{CH}_{4}, \mathrm{Fe}(\mathrm{II})$, $\mathrm{Mn}(\mathrm{II})$, and $\mathrm{CH}_{4}$ were also measured monthly as part of the regular monitoring protocol until 1997. By then, concentrations of reduced substances in the hypolimnion became negligible relative to the $\mathrm{O}_{2}$ budget. The amount of $\mathrm{O}_{2}$ that these reduced compounds consume because of their oxidation in oxic waters was subtracted from the total $\mathrm{O}_{2}$ content of the 


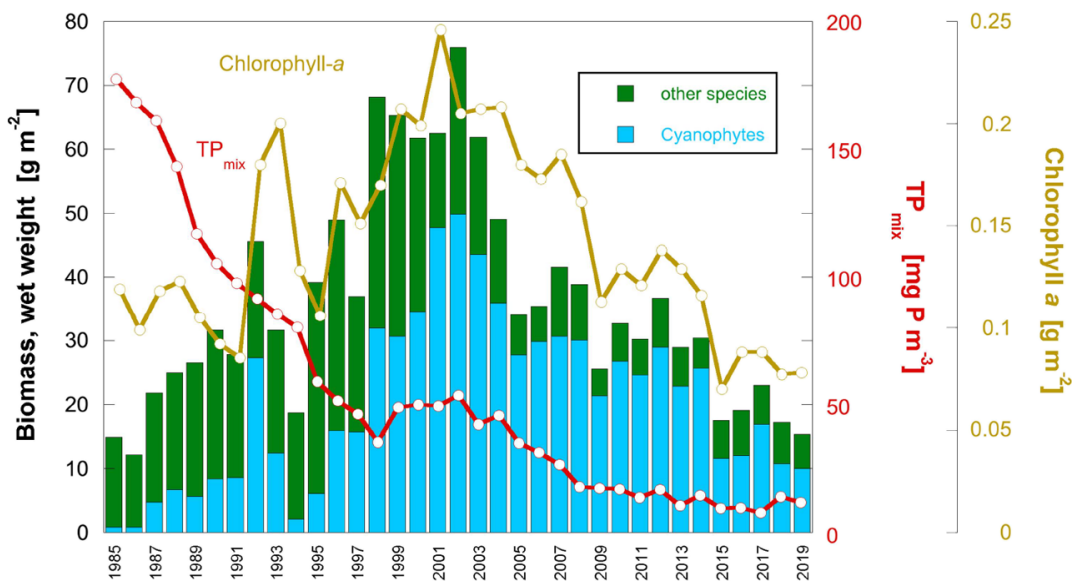

Figure 1. Phytoplankton biomass (annual mean values in $\mathrm{g} \mathrm{m}^{-2}$ wet weight) for Lake Hallwil measured from the monthly samples of the upper 13 $\mathrm{m}$ of the water column. Cyanophytes (blue) were dominated by P. rubescens in most years. Green bars aggregate other major algal classes (Chlorophyceae, Dino- and Cryptophyceae, Chrysophyceae, and diatoms). The red line depicts the $\mathrm{TP}_{\text {mix }}$ concentrations after winter overturn. The tan line represents average annual chlorophyll-a concentrations.

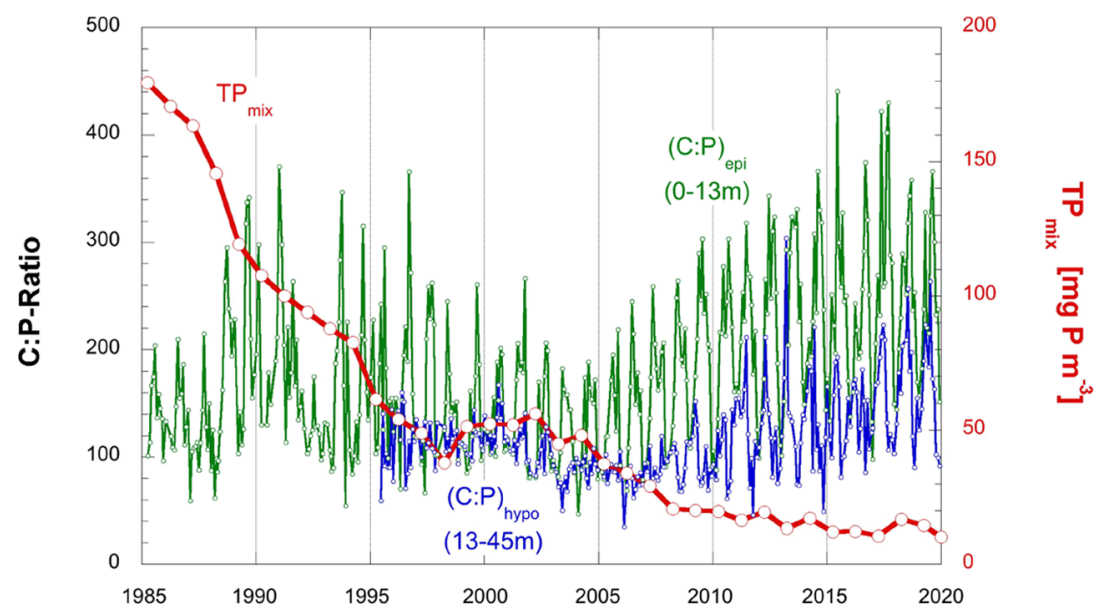

Figure 2. C:P ratios from seston in the epilimnion $\left(0-13 \mathrm{~m}\right.$ depth, green) and in the hypolimnion $\left(13-45 \mathrm{~m}\right.$ depth, blue). $\mathrm{TP}_{\text {mix }}$ represents $\mathrm{TP}$ concentrations after winter overturn (red).

hypolimnion. Multiplication factors for estimating $\mathrm{O}_{2}$ equivalents from the reduced compounds ${ }^{6}$ were 2 for $\mathrm{NH}_{4}{ }^{+}$and $\mathrm{CH}_{4}, 0.5$ for $\mathrm{NO}_{2}^{-}$and $\mathrm{Mn}(\mathrm{II})$, and 0.25 for $\mathrm{Fe}(\mathrm{II})$. The consumption of the corrected $\mathrm{O}_{2}$ content in the hypolimnion was calculated as the difference between the highest (usually in March) and the lowest content (usually early November). The AHM in $\mathrm{O}_{2}$ equivalents was calculated by normalizing to the hypolimnion cross-sectional area at $15 \mathrm{~m}$ depth on a daily basis $\left[\mathrm{g} \mathrm{O}_{2} \mathrm{~m}^{-2} \mathrm{~d}^{-1}\right]$.

2.4. Plankton Sampling and Analysis. Phytoplanktons were sampled monthly using a tubing system suspended within the water column between the depths of $0-13$ and $13-45 \mathrm{~m}$ (details given in chapter S2). The integrated samples were split into duplicates and filtered using glass fiber filters for POC and cellulose acetate membrane filters for PP. Chlorophyll-a was measured photometrically at $665 \mathrm{~nm}$. Phytoplankton analysis used samples from 0 to $13 \mathrm{~m}$ depth preserved in Lugol solution (iodine acetate). Following the Utermöhl technique, ${ }^{28}$ the samples collected throughout the sampling period were concentrated by settling. Organisms were then counted from cell chambers under a microscope. Counts of all visible cells were multiplied by specific cell volumes, assuming a density of
$1 \mathrm{~g} \mathrm{~cm}^{-3}$ to establish estimates of wet biomass $\left(\mathrm{g} \mathrm{m}^{-2}\right)$ for the surface layer of $0-13 \mathrm{~m}$ volume.

\section{RESULTS}

3.1. Plankton Response to Reoligotrophication. During its reoligotrophication, Lake Hallwil experienced a decline in its volume-weighted average TP concentration after winter overturn (Figure 1) from maximum values of $\sim 240 \mathrm{mg}$ $\mathrm{P} \mathrm{m}^{-3}$ in the mid-1970s to the current levels of $\sim 13 \mathrm{mg} \mathrm{P} \mathrm{m}^{-3}$ (average value from 2016-2020). The TP concentrations declined rapidly because of mitigation measures in the catchment, especially in Lake Baldegg upstream. Concentrations of dissolved inorganic P (DIP) decreased below the detection limit in mid-August every year since 1985 (Figure S4). Concentrations of particulate $\mathrm{P}$ in the epilimnion have remained between 10 and $20 \mathrm{mg} \mathrm{P} \mathrm{m}^{-3}$ with occasional excursions slightly over $20 \mathrm{mg} \mathrm{P} \mathrm{m}^{-3}$ in summer. Starting in 2009, TP dropped below $\sim 20 \mathrm{mg} \mathrm{P} \mathrm{m}^{-3}$ and seasonal variations disappeared. Particulate $\mathrm{P}$ has accounted for virtually all measured P. Concentrations for DIP have remained mostly below 1-2 $\mathrm{mg} \mathrm{P} \mathrm{m}^{-3}$ during all seasons.

From 1985 to1998, living phytoplankton biomass in Lake Hallwil increased from $10-15 \mathrm{~g} \mathrm{~m}^{-2}$ to $>60 \mathrm{~g} \mathrm{~m}^{-2}$ as $\mathrm{TP}_{\text {mix }}$ 

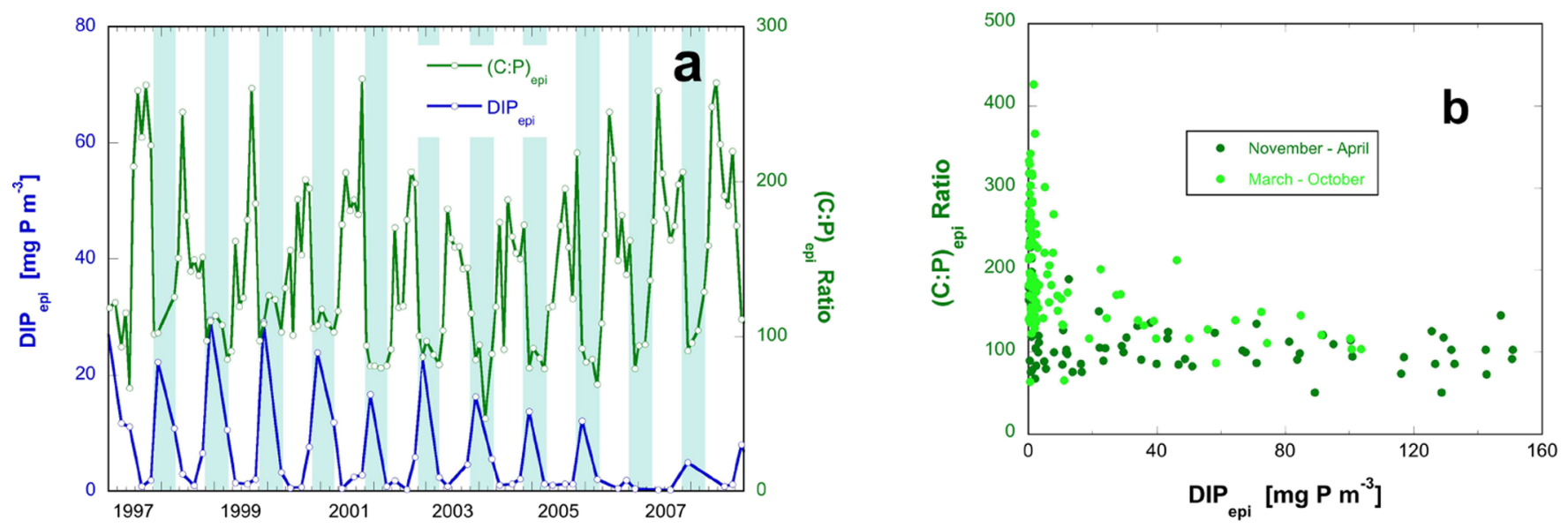

Figure 3. (a) (C:P) epi molar ratios of seston in the epilimnion ( $0-13 \mathrm{~m}$ depth, green) increased immediately after decreases in the volumeaveraged epilimnion concentration of dissolved inorganic P (DIP, blue). Shaded areas depict the timing of deep winter mixing (November to March) and minimal (C:P $)_{\text {epi }}$ values. (b) Drastic increase in $(\mathrm{C}: \mathrm{P})_{\text {epi }}$ occurs only for the lowermost DIP concentration range $\left(<10 \mathrm{mg}^{\mathrm{P}} \mathrm{m}^{-3}\right)$.
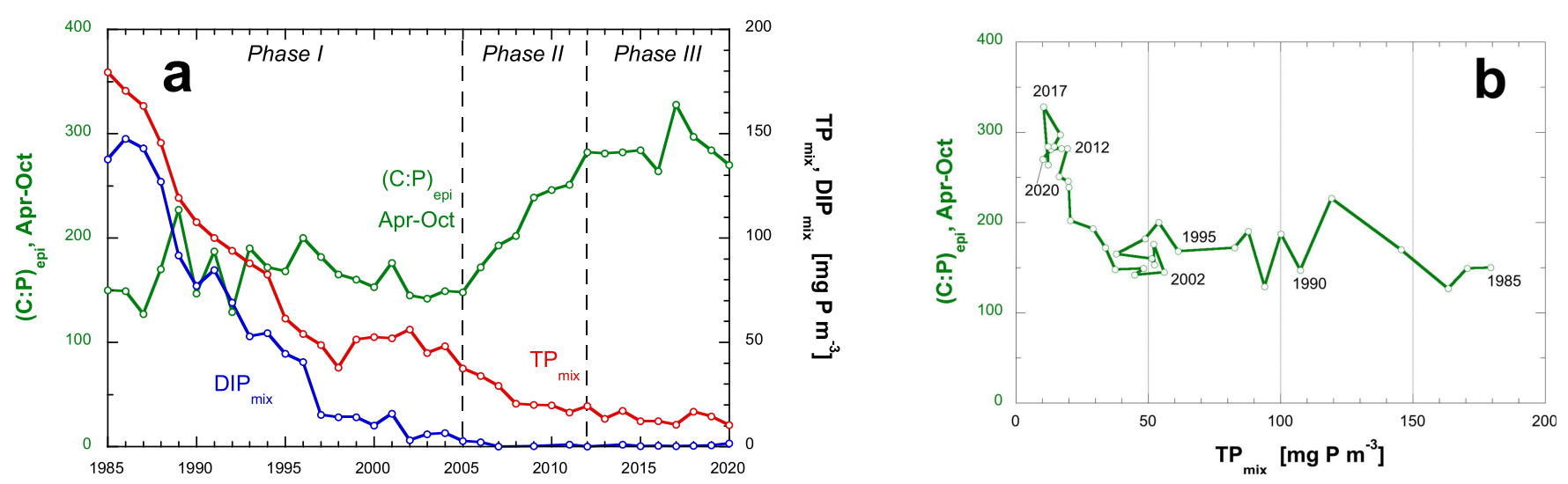

Figure 4. (a) (C:P $)_{\text {epi }}$ molar ratios for seston in the epilimnion $\left(0-13 \mathrm{~m}\right.$ depth) of Lake Hallwil averaged from April to October (green); $\mathrm{TP}_{\text {mix }}$ (red) and $\mathrm{DIP}_{\text {mix }}$ (blue) represent volume-averaged concentrations after winter overturn. (b) Annual averaged (C:P) epi ratios increase below a $\mathrm{TP}_{\text {mix }}$ threshold concentration of $\sim 15$ to $\sim 20 \mathrm{mg} \mathrm{P} \mathrm{m}^{-3}$.

concentrations declined over the course of reoligotrophication. Biomass exhibited maximum values from 1998 to 2003 when $\mathrm{TP}_{\text {mix }}$ concentrations were at $\sim 50 \mathrm{mg} \mathrm{P} \mathrm{m}^{-3}$ (Figure 1). This paradox reflected accumulation of $P$. rubescens communities that often predominate in the metalimnion of lakes during transitions from eutrophic to oligotrophic conditions ${ }^{27,29}$ (see chapter S3 for a concise characterization of $P$. rubescens). Apparently, a $\mathrm{TP}_{\text {mix }}$ concentration of $\sim 50 \mathrm{mg} \mathrm{P} \mathrm{m}^{-3}$ allows for an optimal biomass density in response to light levels and available P. Decreasing TP concentrations were accompanied by an annual mean phytoplankton biomass decline of $\sim 50 \%$ between 2002 and 2005. Phytoplankton species other than $P$. rubescens also declined, allowing $P$. rubescens to consume an even larger fraction of available P. By the mid-2000s, it comprised $75-85 \%$ of the net phytoplankton biomass. Since 2002 , the peak biomass of $P$. rubescens has declined by $\sim 80 \%$ as TP has decreased from maximum values of 50 to $10 \mathrm{~g} \mathrm{~m}^{-3}$ in 2019 (Figure 1). Average annual chlorophyll-a concentrations have followed phytoplankton abundance trends over the years. Secchi depths (Figure S5) were shallow in winter during years of high $P$. rubescens biomass $(<4 \mathrm{~m})$. The years with highest $P$. rubescens and phytoplankton biomass (1998 to the mid-2000's) showed the lowest Secchi depth estimates for all seasons. The depths increased gradually in subsequent years.
3.2. Increasing C:P Ratio of Seston with Decreasing TP Concentrations. While Lake Hallwil $\mathrm{TP}_{\text {mix }}$ concentrations declined from maximum values of $\sim 240 \mathrm{mg} \mathrm{P} \mathrm{m}^{-3}$ in the 1970 s to $\sim 50 \mathrm{mg} \mathrm{P} \mathrm{m}^{-3}$ (average from 1996-2004, red line in Figure 2), the seston $\mathrm{C}: \mathrm{P}$ ratios in the epilimnion and hypolimnion did not show any systematic trend. The molar $\mathrm{C}: \mathrm{P}$ ratios of seston from the epilimnion $(\mathrm{C}: \mathrm{P})_{\text {epi }}$ showed a pronounced seasonality with minimum values in winter $(\sim 110$, December to March, green marks in Figure 2). Individual peaks in the summer months of June to September occasionally exceeded 300. The molar ratio for the hypolimnion ( $(\mathrm{C}: \mathrm{P})_{\text {hypo }}$ for $13-45 \mathrm{~m}$ depth, blue marks in Figure 2) resembled winter values in the epilimnion and showed only weak seasonal dynamics with much lower summer peaks.

Data collected since the mid-2000s show a clear increase in $(\mathrm{C}: \mathrm{P})_{\mathrm{epi}}$ ratios. The summer maximum ratios showed both steady and drastic seasonal increases. The $(\mathrm{C}: \mathrm{P})_{\text {hypo }}$ ratios that thus far showed only minor year-to-year variations but strong seasonality also increased to show seasonal variations of a greater magnitude. The $C: P$ ratios in the epilimnion and hypolimnion were similar during winter overturn, but $(\mathrm{C}: \mathrm{P})_{\mathrm{epi}}$ values were much higher than $(\mathrm{C}: \mathrm{P})_{\text {hypo }}$ during the productive season. Supporting Information (chapter S4) provides a more 
detailed analysis of monthly $(\mathrm{C}: \mathrm{P})_{\mathrm{epi}}$ ratios for different time intervals.

Figure 3a shows the data for the years 1997 to 2008 in greater temporal resolution. Every summer, the sestons' $(\mathrm{C}: \mathrm{P})_{\text {epi }}$ ratio (green line) increased immediately upon the complete consumption of $\mathrm{DIP}_{\text {epi }}$ (blue line) when the concentrations approached a detection limit of $\sim 0.5 \mathrm{mg} \mathrm{P}$ $\mathrm{m}^{-3}$. Figure $3 \mathrm{~b}$ shows that the $(\mathrm{C}: \mathrm{P})_{\text {epi }}$ fell within a narrow range of values (average $110 \pm 35$ ) except for the concentrations of $\mathrm{DIP}_{\text {epi }}$ less than $\sim 12 \mathrm{mg} \mathrm{P} \mathrm{m}^{-3}$. Beneath a threshold of $12 \mathrm{mg} \mathrm{P} \mathrm{m}^{-3}$, the average (C:P) $)_{\text {epi }}$ values were 200 \pm 70 . The seasonal disappearance of $\mathrm{DIP}_{\text {epi }}$ appears to have triggered the increase in the $(\mathrm{C}: \mathrm{P})_{\mathrm{epi}}$ ratio.

\section{DISCUSSION}

4.1. C:P Ratio of Lake Seston in Response to Reoligotrophication. Over the 35 year record for Lake Hallwil, the most pronounced changes in seasonal seston C:P ratios appear in the epilimnion during the productive season. Figure 4a shows annual averaged $(\mathrm{C}: \mathrm{P})_{\text {epi }}$ ratios from April to October as well as $\mathrm{TP}_{\text {mix }}$ and $\mathrm{DIP}_{\text {mix }}$ concentrations for the end of winter overturns. This figure highlights three apparent phases in lake reoligotrophication.

Phase I ( $<\mathbf{1 9 8 5}$ to 2005): In spite of decreasing $\mathrm{TP}_{\text {mix }}$ concentrations, the average annual phytoplankton biomass increased about sixfold and peaked at $\mathrm{TP}_{\text {mix }}$ concentrations of $\sim 50 \mathrm{mg} \mathrm{P} \mathrm{m}{ }^{-3}$. Despite contrasting trends between the biomass and $\mathrm{TP}_{\text {mix }}$ concentrations, the seston $(\mathrm{C}: \mathrm{P})_{\mathrm{epi}}$ ratio remained at $\sim 165$ (average of 1985 to 2005 ), while growth was not limited by $\mathrm{P}$ supply (Figure 4b). P. rubescens became established in the lake by 1987 and predominated lake phytoplankton composition within a few years (Figure 1). The $(\mathrm{C}: \mathrm{P})_{\text {epi }}$ ratio stabilized with decreasing $\mathrm{TP}_{\text {mix }}$ and increasing $P$. rubescens biomass such that variations became less.

Phase II (2005 to 2012): The already low concentrations of immediately available DIP for springtime approached the detection limit, indicating that $\mathrm{P}$ in the productive epilimnion remained bound in the organic form (blue line in Figure 4a). Further decline in TP concentrations forced phytoplanktons to optimize $\mathrm{P}$ usage to maintain high assimilation rates. As a consequence, the $(\mathrm{C}: \mathrm{P})_{\text {epi }}$ ratio for organic particles increased, while the biomass remained roughly constant (Figure 1 ). $\mathrm{TP}_{\text {mix }}$ reached threshold values of $\sim 38 \mathrm{mg} \mathrm{P} \mathrm{m}^{-3}$ when $(\mathrm{C}: \mathrm{P})_{\text {epi }}$ began to increase.

Phase III (2012 to Present Day): Phytoplankton could no longer adjust $\mathrm{C}: \mathrm{P}$ ratios and a further decline in $\mathrm{P}$ concentrations began to limit the phytoplankton biomass. The $(\mathrm{C}: \mathrm{P})_{\text {epi }}$ ratio reached maximum values and remained roughly constant at $\sim 290$ (average from 2012 to 2019). The biomass began decreasing once $\mathrm{TP}_{\text {mix }}$ decreased below a threshold $\mathrm{TP}_{\text {mix }}$ concentration of $\sim 15$ to $\sim 20 \mathrm{mg} \mathrm{P} \mathrm{m}^{-3}$. The biomass decreased by $\sim 50 \%$ during phase III, and continues to consist mostly of $P$. rubescens.

An increase in the (C:P) $)_{\text {epi }}$ ratios from 165 to 290 during the productive seasons coupled with a decline in excess $\mathrm{P}$ (phase I) to P-limited conditions (phase III) agrees well with trends for corresponding trophic scenarios given in the literature. Healey and Hendzel ${ }^{8}$ reported similar C:P ranges for phytoplankton cultures growing under varying nutrient limitations when $\mathrm{P}$ was not limiting ( $: \mathrm{P}<129)$ or severely limiting ( $: \mathrm{P}>258$ ). Guildford and Hecky ${ }^{18}$ reported an average C:P ratio of 265 from several large lakes in northwestern Ontario. Five lakes from the Experimental Lakes Area in Canada having water residence times of $>6$ months showed an average $\mathrm{C}$ : $\mathrm{P}$ ratio of 412. ${ }^{12}$ During the reoligotrophication of Lake Constance, seston C:P ratios increased from $\sim 100\left(\mathrm{TP}_{\text {mix }}=77 \mathrm{mg} \mathrm{P} \mathrm{m}^{-3}\right)$ to $\sim 270\left(\mathrm{TP}_{\text {mix }}=25 \mathrm{mg} \mathrm{P} \mathrm{m}^{-3}\right)$ and showed clear seasonal variations. $^{22}$ Similar to the findings shown in Figure 2, the C:P ratio ranged from 135 to 410 for all individual measurements corresponding to $\mathrm{TP}_{\text {mix }}=25 \mathrm{mg} \mathrm{P} \mathrm{m}$. Sterner et al. ${ }^{30}$ reported a similar seasonal range from 13 lakes of the Red Lake district (Ontario, CA). The oligotrophic Lake Superior exhibits a summer average C:P ratio of 298 for the upper $20 \mathrm{~m}$ of its water column. ${ }^{19}$ Tropical lakes also give C:P ratios in this range. The eutrophic Lake Victoria exhibited a C:P ratio of 149, while that of mesotrophic Lakes $\mathrm{Malawi}^{18}$ and $\mathrm{Kivu}^{31}$ reached values of 244 and 263, respectively. Sterner et al. ${ }^{13}$ estimated an average C:P ratio of 225 using a large data set covering both large and small lakes over all seasons. The C:P range expressed during the reoligotrophication of Lake Hallwil is thus consistent with values observed from other freshwater lakes.

At elevated TP concentrations, the phytoplankton biomass typically dominates the seston composition and may account for nearly all PP in suspension. Excess P supply relative to phytoplankton uptake can lead to luxury uptake of $\mathrm{P}$ which decreases phytoplankton C:P ratios. ${ }^{16,17}$ In an oligotrophic lake, however, allochthonous particles can contribute to and thereby bias PP. Sources and composition of particulate material may vary across lakes. For Lake Hallwil, allochthonous particles are negligible because the lake is surrounded by densely vegetated hills along its western and eastern shores. Its main tributary transports outflow from Lake Baldegg upstream, which provides $\sim 50 \%$ of its hydrological load and acts as sedimentation basin for terrestrial materials.

Figure $4 \mathrm{a}$ shows that the decreasing $\mathrm{TP}_{\text {mix }}$ concentrations during phase I still provided sufficient $\mathrm{P}$ for optimal growth of the phytoplankton community, as indicated by the consistent $(\mathrm{C}: \mathrm{P})_{\mathrm{epi}}$ ratio. These ratios fell well within the range measured from other eutrophic lakes. A $\mathrm{TP}_{\text {mix }}$ value of $\sim 38 \mathrm{mg} \mathrm{P} \mathrm{m}^{-3}$ represented a threshold, wherein $\mathrm{DIP}_{\text {epi }}$ concentrations approached the detection limit following winter overturn. The disappearance of DIP indicated that virtually all $\mathrm{P}$ present occurred as particulate organic $\mathrm{P}$ with no immediately bioavailable $\mathrm{P}$ remaining in the epilimnion. This may not influence increasing $(\mathrm{C}: \mathrm{P})_{\text {epi }}$ ratios because even if DIP fell within a measurable range at the beginning of the productive season, it becomes depleted almost immediately when production sets in. Figure S4b shows that already by 1985, DIP concentrations had become depleted in the epilimnion shortly after the onset of production in spring. Biomass remained approximately constant in its quantity and composition after 2005, but increasing $(\mathrm{C}: \mathrm{P})_{\mathrm{epi}}$ ratios indicate that phytoplankton had optimized the consumption of $\mathrm{P}$ to maintain maximum production. A second threshold was reached when the $(\mathrm{C}: \mathrm{P})_{\text {epi }}$ ratio of seston attained levels associated with $\mathrm{TP}_{\text {mix }}$ concentrations of $15-20 \mathrm{mg} \mathrm{P} \mathrm{m}^{-3}$ (Figure 4b). A (C:P) epi ratio of $\sim 290$ persisted through the subsequent years and resembled values observed in other oligotrophic lakes. Biomass has since declined up until present day, and annual $\mathrm{TP}_{\text {mix }}$ concentrations have decreased to values as low as $10 \mathrm{mg} \mathrm{P} \mathrm{m}^{-3}$. The threshold $\mathrm{TP}_{\text {mix }}$ concentration of $15-20 \mathrm{mg} \mathrm{P} \mathrm{m}^{-3}$ agrees with the recent estimates by Müller et $\mathrm{al}^{4}$ which use the change in hypolimnetic mineralization rate as an indicator of trophic development. They estimate the eventual decrease of the net ecosystem production (NEP, i.e., 
the amount of organic carbon exported from the productive zone to the hypolimnion) below a threshold value corresponding to an areal $\mathrm{P}$ load of $\sim 0.54 \mathrm{~g} \mathrm{P} \mathrm{m}^{-2}$ during a lake's productive season. For Lake Hallwil, this load corresponds to a $\mathrm{TP}_{\text {mix }}$ concentration of $\sim 20 \mathrm{mg} \mathrm{P} \mathrm{m}^{-3}$, as shown in chapter S5.

4.2. Further Indicators of Lake Recovery. The indicators of lake recovery from excess $\mathrm{P}$ loads include decreasing concentrations of $\mathrm{TP}_{\text {mix }}$ DIP, and PP (Figure S4), decreasing phytoplankton biomass and chlorophyll-a concentrations (Figure 1), and increasing Secchi depths. The last parameter has approximately doubled since the mid-2000s for all seasons (Figure S5). The input of molecular $\mathrm{O}_{2}$ to sustain an oxic hypolimnion was reduced from an average $537 \mathrm{t} \mathrm{O}_{2}$ per summer (1987-2007) to 109 t $_{2}$ (2016-2019) (Section 4.3 and Figure S7). Local fishermen report that fish have become slimmer and longer and that recent fish catch has declined. Sediment trap data from Lake Hallwil showed that the sedimentation rate for organic carbon declined from $123 \mathrm{~g} \mathrm{C}$ $\mathrm{m}^{-2}$ year $^{-1}$ in $1982^{20}$ (C:P $=130$, May to October, $30 \mathrm{~m}$ depth) to $52 \pm 7 \mathrm{~g} \mathrm{C} \mathrm{m}^{-2}$ year $^{-1}$ (2014-2016, C:P = $200 \pm$ 54, April to October, $30 \mathrm{~m}$ depth). ${ }^{4}$ These observations indicate that NEP has decreased by more than $50 \%$ over the last $\sim 30$ years, and trophic conditions have shifted from Psufficient to P-limited. Comparison of C:P measurements, obtained from sediment traps and tube samples, showed that sediment traps provided consistently lower estimates. These lower C:P ratios may reflect the mineralization of organic matter or grazing by crustaceans in the traps during collection. $^{32}$

4.3. Evidence of Decreasing Production from Hypolimnetic Oxygen Consumption. The decreasing trend of AHM, and by extension also of NEP, since about 2012 occurred simultaneously with the continued decline of $\mathrm{TP}_{\text {mix }}$ and biomass under persistently high $(\mathrm{C}: \mathrm{P})_{\text {epi }}$ ratios. Figure 5

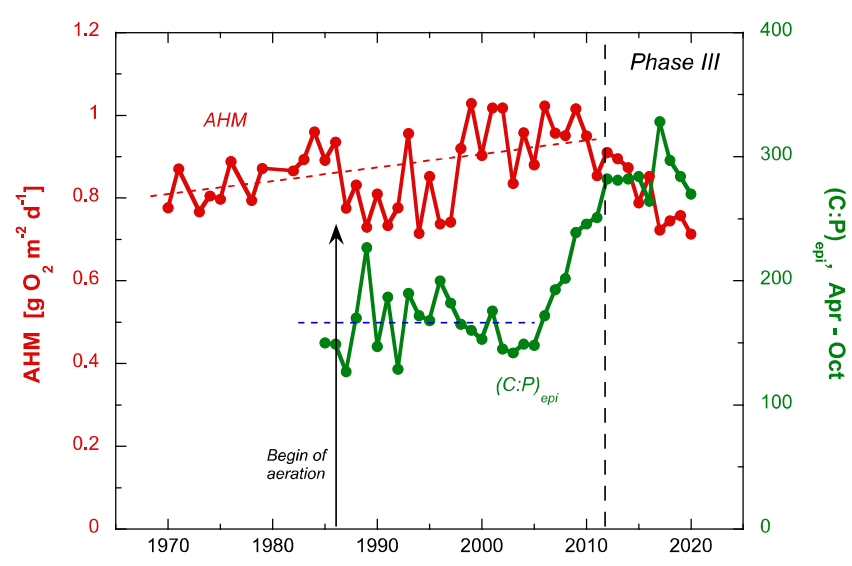

Figure 5. Areal hypolimnetic mineralization rate (AHM, red) during summer stratification and seasonal $(\mathrm{C}: \mathrm{P})_{\mathrm{epi}}$ ratios averaged from April to October (green). The arrow indicates the initiation of aeration in 1986.

shows the AHM evolution over the past 50 years. The areal rate of $\mathrm{O}_{2}$ introduced by aeration is subtracted from the observed AHM. The AHM depicted in Figure 5 thus represents net $\mathrm{O}_{2}$ depletion values (AHMs not corrected for aeration are shown in Figure S7 and discussed in chapter S6). The decline in AHM observed over the last decade is consistent with the observed decline in biomass (Figure 1) and the stabilization of seston $(\mathrm{C}: \mathrm{P})_{\mathrm{epi}}$ ratios in phase III
(Figure 5). These trends coincided with $\mathrm{TP}_{\text {mix }}$ concentrations attaining threshold values of $15-20 \mathrm{mg} \mathrm{P} \mathrm{m}^{-3}$. Together, the trends in biomass, $(\mathrm{C}: \mathrm{P})_{\mathrm{epi}}$, and $\mathrm{TP}_{\text {mix }}$ thresholds indicate decreasing NEP, eventually resulting in decreasing $\mathrm{O}_{2}$ consumption resulting from lake reoligotrophication.

4.4. Trends of C:P Ratios in Lakes Undergoing Reoligotrophication. Our analysis of processes that led to the reoligotrophication of Lake Hallwil suggests that phytoplankton communities make an initial adjustment to changing water column conditions. This adjustment appears as an increase in $(\mathrm{C}: \mathrm{P})_{\text {epi }}$ ratios during the productive season. The $(\mathrm{C}: \mathrm{P})_{\mathrm{epi}}$ ratios from four other temperate, seasonally stratified lakes progressing toward reoligotrophication also show this increase. Figure 6 shows the inverse relations between $(\mathrm{C}: \mathrm{P})_{\text {epi }}$

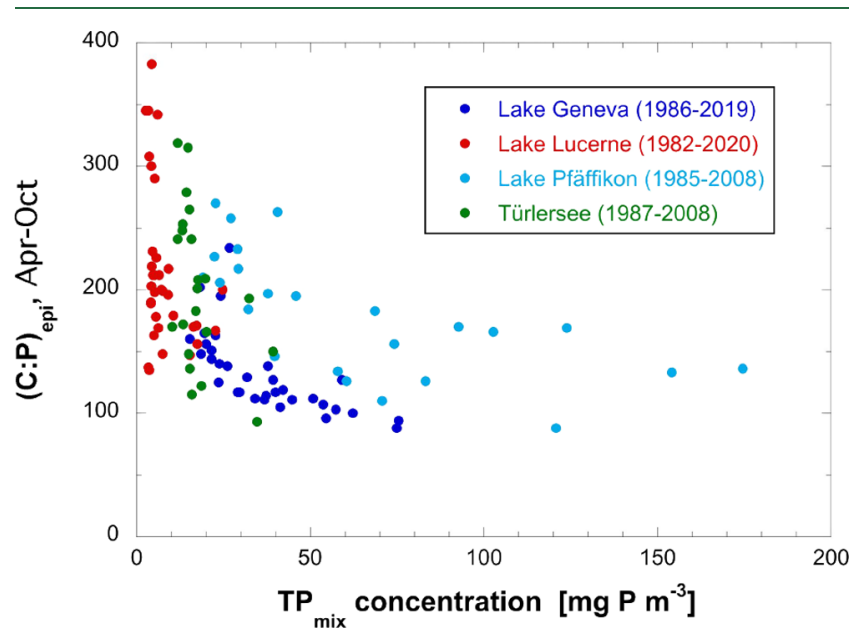

Figure 6. Average $(\mathrm{C}: \mathrm{P})_{\text {epi }}$ ratios for seston in the epilimnion during the stratified season (April to October) for four lakes undergoing reoligotrophication. Lakes include Lake Geneva (34 years of monitoring data, blue), Lake Lucerne (39 years of data, red), Lake Pfäffikon (24 years of data, light blue), and Türlersee (20 years of data, green).

ratios and $\mathrm{TP}_{\text {mix }}$ concentrations observed from four lakes. The monitoring data shown cover 20 to 35 years. Concentrations of $\mathrm{TP}_{\text {mix }}$ averaged for the past 10 years for Lakes Geneva, Lucerne, Pfäffikon, and Türlersee are 20,4.2, 17, and $18 \mathrm{mg} \mathrm{P}$ $\mathrm{m}^{-3}$, respectively (Table S2). According to Müller et al. ${ }^{4}$ (also see chapter S5), a decline in NEP is predicted to occur at TP concentrations of $20,14,19$, and $16 \mathrm{mg} \mathrm{P} \mathrm{m}^{-3}$ for Lakes Geneva, Lucerne, Pfäffikon, and Türlersee, respectively. Therefore, these lakes are presently at the threshold concentration for $\mathrm{TP}_{\text {mix }}$, below which a decrease in NEP is expected. Only Lake Lucerne has reached its estimated threshold concentration already in 1988. This lake has shown a significant decrease in the AHM. The other three lakes have shown little changes in the AHM until today.

In all four lakes, the increase in the $(\mathrm{C}: \mathrm{P})_{\text {epi }}$ ratio provided initial indications of declining $\mathrm{P}$ concentrations affecting the phytoplankton community. Except for Lake Lucerne, the lakes have shown only small shifts in the AHM. Significant changes in NEP have not yet occurred and require further decline in bioavailable $\mathrm{P}$. Once the lake achieves threshold $\mathrm{TP}_{\text {mix }}$ concentrations, a decline in biomass and associated hypolimnetic $\mathrm{O}_{2}$ consumption would initiate decreases in NEP.

The phytoplankton community reacted to the declining availability of $\mathrm{P}$ during the productive season by improving the efficiency of biomass production and using less P. Rigorous 
detection of this process demonstrates that the $(\mathrm{C}: \mathrm{P})_{\text {epi }}$ ratio detects the declining productivity prior to traditional indicators of deep-water $\mathrm{O}_{2}$ depletion. Long-term data sets containing particle analyses are only available for a few lakes. Future research should seek to verify whether the dynamics observed from Lake Hallwil justify the refining approaches in interpreting the timing of changes in the lake trophic structure.

\section{ASSOCIATED CONTENT}

\section{(s) Supporting Information}

The Supporting Information is available free of charge at https://pubs.acs.org/doi/10.1021/acs.est.0c08526.

Loads of bioavailable phosphorus to Lake Hallwil; tubing system for the integrated sampling of the lake water column; characteristics of Planktothrix rubescens; box plots of epilimnetic C:P ratios at monthly resolution; estimation of the $\mathrm{TP}_{\text {mix }}$ threshold concentration below which NEP decreases in proportion to decreasing $\mathrm{TP}_{\text {mix }}$; evidence of decreasing production from hypolimnetic oxygen consumption; concentration of $\mathrm{O}_{2}$ in the hypolimnion of Lake Hallwil; annual loads of bioavailable $\mathrm{P}$ to Lake Hallwil; comparison of analytical methods for measuring $(\mathrm{C}: \mathrm{P})_{\mathrm{epi}}$ ratios in seston from the epilimnion of Lake Hallwil from 1985 to 2019; volume-weighted average concentrations of total $P$, dissolved inorganic $P$, and particulate $P$ in the epilimnion of Lake Hallwil over the past 40 years; Secchi depth measurements for Lake Hallwil; box plots of $(\mathrm{C}: \mathrm{P})_{\mathrm{epi}}$ in Lake Hallwil; areal hypolimnetic mineralization rate and seasonal $(\mathrm{C}: \mathrm{P})_{\text {epi }}$ ratios; threshold concentrations of $\mathrm{TP}_{\text {mix }}$ calculated for Lakes Geneva, Lucerne, Pfäffikon, and Türlersee; and morphological and hydrological characteristics of Lake Hallwil and the lakes presented in Section 4.4 (PDF)

\section{AUTHOR INFORMATION}

\section{Corresponding Author}

Beat Müller - Surface Waters-Research and Management, Eawag, Swiss Federal Institute of Aquatic Science and Technology, Kastanienbaum 6047, Switzerland;

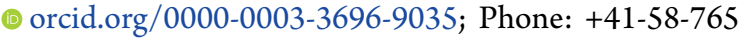

21 49; Email: beat.mueller@eawag.ch

\section{Authors}

Thomas Steinsberger - Surface Waters-Research and Management, Eawag, Swiss Federal Institute of Aquatic Science and Technology, Kastanienbaum 6047, Switzerland

Arno Stöckli - Department of Civil Engineering, Transportation and Environment, Canton Argovia, Aarau 5001, Switzerland

Alfred Wüest - Surface Waters-Research and Management, Eawag, Swiss Federal Institute of Aquatic Science and Technology, Kastanienbaum 6047, Switzerland; Physics of Aquatic Systems Laboratory, Margaretha Kamprad Chair, ENAC-IEE- APHYS, Ecole Polytechnique Fédérale de Lausanne (EPFL), Lausanne 1015, Switzerland

Complete contact information is available at: https://pubs.acs.org/10.1021/acs.est.0c08526

\section{Notes}

The authors declare no competing financial interest.

\section{ACKNOWLEDGMENTS}

We acknowledge the Department of Civil Engineering, Transportation, and Environment, Aarau, for providing monitoring data on Lake Hallwil. SOERE OLA-IS, INRA Thonon-les-Bains, CIPEL, developed by Eco-Informatics ORE INRA Team provided data from Lake Geneva. ${ }^{33}$ Data from Lake Pfäffikon and Türlersee were made available by Amt für Abfall, Wasser, Energie und Luft (AWEL) of the Canton of Zürich. We gratefully acknowledge Isabel Kiefer and René Gächter for helpful discussions and review of the manuscript and Hansruedi Bürgi for providing plankton data. This work was supported by the Swiss National Science Foundation grant 'Primary production under oligotrophication in lakes' (grant no. 200021_179123) and from the Swiss Federal Office of the Environment (FOEN) grant 'Primärproduktion in Seen unter Oligotrophierung'.

\section{REFERENCES}

(1) Hering, J. G.; Hoehn, E.; Klinke, A.; Maurer, M.; Peter, A.; Reichert, P.; Robinson, C.; Schirmer, K.; Schirmer, M.; Stamm, C.; Wehrli, B. Moving targets, long-lived infrastructure, and increasing needs for integration and adaptation in water management: An illustration from Switzerland. Environ. Sci. Technol. 2012, 46, 112118.

(2) Schindler, P. W.; Carpenter, S. R.; Capra, S. C.; Hecky, R. E.; Orihel, D. M. Reducing phosphorus to curb lake eutrophication is a success. Environ. Sci. Technol. 2016, 50, 8923-8929.

(3) Müller, B.; Bryant, L. D.; Matzinger, A.; Wüest, A. Hypolimnetic oxygen depletion in eutrophic lakes. Envir. Sci. Technol. 2012, 46, 9964-9971.

(4) Müller, B.; Steinsberger, T.; Schwefel, R.; Gächter, R.; Sturm, M.; Wüest, A. Oxygen consumption in seasonally stratified lakes decreases only below a marginal phosphorus threshold. Sci. Rep. 2019, 9, 18054.

(5) Lepori, F.; Capelli, C. Effects of phosphorus control on primary productivity and deep-water oxygenation: insights from Lake Lugano (Switzerland and Italy). Hydrobiologia 2021, 848, 613-629.

(6) Matzinger, A.; Müller, B.; Niederhauser, P.; Schmid, M.; Wüest, A. Hypolimnetic oxygen consumption by sediment-based reduced substances in former eutrophic lakes. Limnol. Oceanogr. 2010, 55, 2073-2084.

(7) Steinsberger, T.; Schmid, M.; Gerber, C.; Shafei, B.; Wehrli, B.; Müller, B. Modelling sediment oxygen demand in a highly productive lake under various trophic scenarios. PLoS One 2019, 14, No. e0222318.

(8) Healey, F. P.; Hendzel, L. L. Physiological indicators of nutrient deficiency in lake phytoplankton. Can. J. Fish. Aquat. Sci. 1980, 37, $442-453$.

(9) Elser, J. J.; Chrzanowski, T. H.; Sterner, R. W.; Schampel, J. H.; Foster, D. K. Elemental ratios and the uptake and release of nutrients by phytoplankton and bacteria in three lakes of the Canadian shield. Microb. Ecol. 1995, 29, 145-162.

(10) Moreno, A. R.; Martiny, A. C. Ecological stoichiometry of ocean plankton. Annu. Rev. Mar. Sci. 2018, 10, 43-69.

(11) Sas, H. (ed.) Lake Restoration by Reduction of Nutrient Loading: Expectations, Experiences and Extrapolations; Academia Verlag Richarz, St Augustin, FRG: 1989, 497

(12) Hecky, R. E.; Campbell, P.; Hendzel, L. L. The stoichiometry of carbon, nitrogen, and phosphorus in particulate matter of lakes and oceans. Limnol. Oceanogr. 1993, 38, 709-724.

(13) Sterner, R. W.; Andersen, T.; Elser, J. J.; Hessen, D. O.; Hood, J. M.; McCauley, E.; Urabe, J. Scale-dependent carbon:nitrogen:phosphorus seston stoichiometry in marine and freshwaters. Limnol. Oceanogr. 2008, 53, 1169-1180.

(14) Sterner, R. W.; Elser, J. J. Ecological stoichiometry: The biology of elements from molecules to the biosphere; Princeton Univ. Press: Princeton, NJ, 2002. 
(15) Elser, J. J.; Kyle, M.; Learned, J.; McCrackin, M. L.; Pearce, A.; Steger, L. Life on the stoichiometric knife-edge: effects of high and low food C:P ratio on growth, feeding, and respiration in three Daphnia species. Inland Waters 2016, 6, 136-146.

(16) Frassl, M. A.; Rothhaupt, K. O.; Rinke, K. Algal internal nutrient stores feedback on vertical phosphorus distribution in large lakes. J. Great Lakes Res. 2014, 40, 162-172.

(17) Powell, N.; Shilton, A. N.; Pratt, S.; Chisti, Y. Factors influencing luxury uptake of phosphorus by microalgae in waste stabilization ponds. Environ. Sci. Technol. 2008, 42, 5958-5962.

(18) Guildford, S. J.; Hecky, R. E. Total nitrogen, total phosphorus, and nutrient limitation in lakes and oceans: Is there a common relationship? Limnol. Oceanogr. 2000, 45, 1213-1223.

(19) Sterner, R. W. C:N:P stoichiometry in Lake Superior: freshwater sea as end member. Inland Waters 2011, 1, 29-46.

(20) Gächter, R.; Bloesch, J. Seasonal and vertical variation in the $\mathrm{C}: \mathrm{P}$ ratio of suspended and settling seston of lakes. Hydrobiologia 1985, 128, 193-200.

(21) Bloesch, J.; Uehlinger, U. Horizontal sedimentation differences in a eutrophic Swiss lake. Limnol. Oceanogr. 1986, 31, 1094-1109.

(22) Hochstädter, S. Seasonal changes of C:P ratios of seston, bacteria, phytoplankton and zooplankton in a deep, mesotrophic lake. Freshwater Biol. 2000, 44, 453-463.

(23) Healey, F. P.; Hendzel, L. L. Indicators of phosphorus and nitrogen deficiency in five algae cultures. Can. J. Fish. Aquat. Sci. 1979, 36, 1364-1369.

(24) McGinnis, D. F.; Lorke, A.; Wüest, A.; Stöckli, A.; Little, J. C. Interaction between a bubble plume and the near field in a stratified lake. Water Resour. Res. 2004, 40, No. W10206.

(25) Wehrli, B.; Lotter, A. F.; Schaller, T.; Sturm, M. Highresolution varve studies in Baldeggersee (Switzerland): Project overview and limnological background data. Aquatic Sci. 1997, 59, 285-294.

(26) Gächter, R.; Wehrli, B. Ten years of artificial mixing and oxygenation: no effect on the internal phosphorus loading of two eutrophic lakes. Environ. Sci. Technol. 1998, 32, 3659-3665.

(27) Dokulil, M. T.; Teubner, K. Deep living Planktothrix rubescens modulated by environmental constraints and climate forcing. Hydrobiologia 2012, 698, 29-46.

(28) Bürgi, H. R.; Jolidon, C. 10 Jahre Seesanierung Hallwilersee. Die Reaktion des Planktons. Wasser Energie. Luft. 1998, 90, 109-116 https://www.dora.lib4ri.ch/eawag/islandora/object/eawag:3723.

(29) Posch, T.; Köster, O.; Salcher, M. M.; Pernthaler, J. Harmful filamentous cyanobacteria favoured by reduced water turnover with lake warming. Nat. Climate Change 2012, 2, 809-813.

(30) Sterner, R. W.; Elser, J. J.; Fee, E. J.; Guildford, S. J.; Chrzanowski, T. H. The light:nutrient ratio in lakes: The balance of energy and materials affect ecosystem structure and process. Amer. Natural. 1997, 150, 663-684.

(31) Darchambeau, F.; Sarmento, H.; Descy, J.-P. Primary production in a tropical large lake: The role of phytoplankton composition. Sci. Tot. Environ. 2014, 473-474, 178-188.

(32) Uehlinger, U.; Bloesch, J. Variation in the C:P ratio of suspended and settling seston and its significance for $\mathrm{P}$ uptake calculations. Freshwater Biol. 1987, 17, 99-108.

(33) Rimet, F.; Anneville, O.; Barbet, D.; Chardon, C.; Crepin, L.; Domaizon, I.; Dorioz, J.-M.; Espinat, L.; Frossard, V.; Guillard, J.; Goulon, C.; Hamelet, V.; Hustache, J.-C.; Jacquet, S.; Laine, L.; Montuelle, B.; Perney, P.; Quetin, P.; Rasconi, S.; Schellenberger, A.; Tran-Khac, V.; Monet, G. The Observatory on LAkes (OLA) database: Sixty years of environmental data accessible to the public. J. Limnol. 2020, 79, 164-178. 